\title{
Hypothyroidism and Leptin in Iraqi Patients with Chronic Kidney Disease
}

\author{
Athraa K. Falhi ${ }^{I} \quad$ Noori M. Luaibi ${ }^{* 1}$ \\ Ali J. Alsaedi ${ }^{2}$ \\ ${ }^{1}$ Biology Department, College of Science, Mustansiriyah University, Baghdad, Iraq. \\ ${ }^{2}$ Consultant Nephrologist, Medical City, Baghdad, Iraq. \\ *Corresponding author: athraa.khalf@yahoo.com, sznl@uomustansiriyah.edu.iq., alsaedinephrology@gmail.com \\ *ORCID ID: https://orcid.org/0000-0002-7572-4121
}

Received 6/7/2019, Accepted 25/10/2020, Published 20/6/2021

This work is licensed under a Creative Commons Attribution 4.0 International License.

\begin{abstract}
The present study aims at assessing the effects of chronic kidney disease (CKD) on thyroid hormone and leptin by evaluating the level of: leptin hormone along with thyroid hormone in CKD patients. The study has been conducted on 70 subjects, 50 patients with an age range between 20-50 years ( 25 males and 25 females) who were diagnosed to have CKD stage-5, and 20 normal controls whose ages ranged between 20-48 years (10 males and 10 females), who attended the Nephrology and Transplant Center in Medical City of Baghdad- Iraq from April 2018 to July 2018. The study showed a highly significant $(\mathrm{P}<0.01)$ increase in TSH level in CKD patients in comparison with controls. While T3 and T4 levels observed highly significant decrease $(\mathrm{P}<0.01)$ in CKD patients in comparison with their control groups; on the other hand, in Leptin levels, it has been demonstrated a highly significant $(\mathrm{P}<0.01)$ increase in $\mathrm{CKD}$ patients compared to the controls. Also there was a significant $(\mathrm{P}<0.05)$ positive correlation between TSH and Leptin, while the results showed a highly significant $(\mathrm{P}<0.01)$ negative correlation between $\mathrm{T} 3, \mathrm{~T} 4$ and Leptin. To conclude, this study confirms that thyroid dysfunction and hyperleptinemia have been found to be very common in CKD patients and reveals the significant association between CKD progression and thyroid dysfunction and hyperleptinemia.
\end{abstract}

Key words: CKD, Hypothyroidism, Leptin, TSH, T3.

\section{Introduction}

Chronic kidney disease is a common outcome of various kidney diseases that cause a series of refractory complications, which leads to great economic burdens on patients (1). The thyroid gland located at the interior part of the neck, secretes two major hormones $\mathrm{T} 4$ and $\mathrm{T} 3$, respectively that have many actions including metabolism, development, protein synthesis, and the regulation of many other important hormones (2). Thyroid epithelial cells are arranged in spheres called thyroid follicles in which thyroid hormone is synthesized by the iodination of tyrosine residues in the glycoprotein thyroglobulin (3). Kidneys are involved in the metabolism and elimination of thyroid hormones, CKD affects thyroid function in many ways, including low circulating thyroid hormone levels, altered peripheral hormone metabolism, insufficient binding to carrier proteins, reduced tissue thyroid hormone content and altered iodine storage in the thyroid gland, thus, in CKD, thyroid hormone metabolism is impaired $(4,5)$.
Leptin is a peptide hormone, produced in adipose tissues, plays an important role in regulating food consumption and energy expenditure (6). There is an increasing interest in the relationship between adipokines secreted by adipose tissues and kidney disease (7). Elevated leptin levels have been constituently shown to be associated with CKD in public population as well as among diabetic and obese non diabetic patients (8). Although leptin is a $16 \mathrm{KDa}$ molecule that execrated by the kidney, the relative contribution of decreased renal clearance to total serum leptin is not known, increased production is an associated potential causes of hyperleptinemia in CKD $(9,10)$.

\section{Material and Methods:}

This study was carried out at Nephrology and Transplant Center in Medical City of Baghdad- Iraq from April 2018 to July 2018. The study included two 
groups: patients and control groups. Patients group included 50 that were diagnosed to have end stage renal diseases, their ages ranged between 20-50 years (25 males and 25 females), those patients diagnosed by the consultant medical staff at the clinic. Concerning patients who were pregnant with history of hyper or hypothyroidism or who were on or underwent previous dialysis were excluded. The control groups were 20 whose ages ranged between 20-48 years (10 males and 10 females). Blood samples were collected from all groups for estimation of TSH, T3,T4 and leptin. Thyroid hormones were estimated in serum of all subjects by using an automated quantitative COBAS e411 test (from Roche company, Germany). While serum Leptin was measured by ELISA using a kit supplied by Demeditec Diagnostics GmbH- Germany. The Statistical Analysis System- SAS (2012) program was used to affect different factors in study parameters.

\section{Results}

The main findings of this study are as follows: Table 1 displays that TSH level in patients group $(12.12 \pm 1.97)$ showed a high significant elevation $(\mathrm{P}<0.01)$ in comparison with control $(1.73 \pm 0.24)$, while T3 level showed a highly significant reduction $(\mathrm{P}<0.01)$ in CKD group $(0.970 \pm 0.05)$ in comparison with control $(1.43 \pm 0.11)$, also $\mathrm{T} 4(6.81 \pm 0.32)$ showed a highly significant reduction $(\mathrm{P}<0.01)$ in CKD groups when compared with control group (9.21 $\pm 0.25)$.

Table 1. Comparison the levels of TSH, T3 and T4 between the patients and healthy (control)groups

\begin{tabular}{|c|c|c|c|}
\hline \multirow[t]{3}{*}{ Group } & \multicolumn{3}{|c|}{ Thyroid function tests (Mean \pm} \\
\hline & \multicolumn{3}{|c|}{ SE) } \\
\hline & $\begin{array}{c}\text { TSH } \\
\mathrm{mu} / \mathrm{ml}\end{array}$ & $\begin{array}{c}\text { T3 } \\
\mathrm{ng} / \mathrm{ml}\end{array}$ & $\begin{array}{r}\mathrm{T4} \\
\mathrm{mg} / \mathrm{dl}\end{array}$ \\
\hline Patients & $12.12 \pm$ & 0.970 & $6.81 \pm$ \\
\hline (N. 50) & 1.97 & \pm 0.05 & 0.32 \\
\hline Control & 1.73 & $1.43 \pm$ & $9.21 \pm$ \\
\hline s (N. 25) & 0.24 & 0.11 & 0.25 \\
\hline T-Test & $6.256 * *$ & 0.229 & 1.059 \\
\hline & & ** & ** \\
\hline P-value & 0.0015 & 0.000 & 0.000 \\
\hline ** $(\mathrm{P}<$ & : Highly Si & $\begin{array}{l}1 \\
\text { ficant }\end{array}$ & 1 \\
\hline
\end{tabular}

The observed results in Table 2 shows a highly significant increase in Leptin levels in the majority of the patients with CKD inspected in this study in respect to the patients whose mean level was $(167.70 \pm 12.71)$ as compared to the mean level in control $(99.12 \pm 16.41 \mathrm{pg} / \mathrm{ml})$. Statistical analysis revealed that there are significant differences with probability $(\mathrm{P}<0.01)$.

Table 2. Comparison of Leptin level between patients and control groups.

\begin{tabular}{ll} 
Group & $\begin{array}{c}\text { Leptin } \mathbf{n g} / \mathbf{m l} \\
\text { Mean } \pm \text { SE }\end{array}$ \\
\hline Patients & $167.70 \pm 12.71$ \\
Control & $99.12 \pm 16.41$ \\
T-Test & $45.19 * *$ \\
P-value & 0.0035 \\
$* *(\mathrm{P}<0.01):$ Highly Significant \\
\hline
\end{tabular}

The findings in Table 3 indicate a correlation coefficient between thyroid hormone and other parameters in this study. As it showed positive correlation between TSH and Leptin, and there is a negative correlation between $\mathrm{T} 3$ and Leptin. In addition, there was a negative correlation between $\mathrm{T} 4$ and Leptin.

Table 3. Correlation coefficient between TSH, T3, T4 and Leptin

\begin{tabular}{lccl}
\hline \multirow{2}{*}{ Parameters } & \multicolumn{3}{c}{ Correlation } \\
and Level of significant & \multicolumn{2}{c}{ coefficient-r } \\
& TSH & T3 & T4 \\
\hline Leptin & 0.25 & -0.38 & -0.27 \\
NS & & & \\
\hline
\end{tabular}

\section{Discussion:}

Reports suggest that progression of CKD is associated with having a number of complications, including thyroid dysfunction (4). Impairment in kidney function leads to disturbed thyroid physiology, all levels of the hypothalamic pituitary thyroid axis may be involved, including alterations in hormone production, distribution, and excretion (11). Leptin is linked to the development of CKD in the absence of obesity, as patients with ESRD have an estimated 47.5 fold increase in plasma leptin concentration (hyperleptinemia) compared with healthy control subjects (12).

The present study showed a high significant $(\mathrm{P}<0.01)$ elevation in serum TSH levels in CKD patients when compared to control group. Another study is in agreement with this study and this may be attributed to the fact that TSH elevation may be due to elevation of the TRH from the hypothalamus (13) and intact thyroid pituitary axis (14). These finding are similar to the results from (15), who showed significant increase in the level of TSH in the CKD patients compared with the controls. In the existing 
study, serum T3, T4 levels revealed a high significant $(\mathrm{P}<0.01)$ decrease in $\mathrm{CKD}$ patients as compared with control group, the similar result reported by many other authors $(11,16,17)$. The result of current study is in conflict with study done by Khatiwada et al., (18), who observed decreasing trend for T3 and T4 levels (though the decrease was not significant), and increasing trend for TSH level (significant rise) across CKD stages 3-5, which suggest that TSH level increases with the progression of renal impairment.

From the various studies, it has been suggested that this thyroid profile derangements were part of body adaptation mechanism to conserve energy (2). In light of these findings, a high rate of abnormal thyroid hormone profile in CKD patients, as observed in this study, may be due to excess iodine nutrition or iodine deficiency, or prevalence of thyroid autoimmunity in study population and the presence of subjects with non-thyroidal illness.

The results of this study were in agreement with the results found by Aminzadeh et al., (19), who showed increased serum Leptin level in patients with CKD compared to control and concluded exposure to uremic plasma induces exuberant release of leptin that is coupled with avid uptake of TNF- $\alpha$ by visceral adipocytes. Plasma leptin concentration increased in patients with CKD as its clearance was decreased in the failing kidney, and this increased level was positively correlates with CKD severity $(20,21)$. Other studies have also reported similar findings such as (22), who approved that Leptin was markedly elevated in patients with CKD.

The association between leptin and thyroid hormone has been assessed in several studies, but conflicting results have been reported. The present study showed not significant negative correlation between leptin and T3, T4 and not significant positive correlation with TSH. This result was in agreement with many others studies which reported the same result $(23,24,25)$. In a study done by Hsieh et al., (26), on evaluation of leptin serum concentrations in patients with abnormal thyroid function, it seems that leptin level increased in patients with low T3,T4 levels and elevated levels of TSH, and this finding is in agreement with the results of this study. In another study by Corbetta et al., (27), showed that there was no correlation between thyroid hormones and leptin and this result showed a disagreement with the results of this study. The findings of a study done in Iraq by Ibrahim et al., (28), showed that leptin hormone was not significantly correlated with thyroid hormone function. This might be explained by the limited number of participants and lack of over weigh and obese participants included.

\section{Conclusions:}

This study confirms that thyroid dysfunction and hyperleptinemia have been found to be very common in CKD patients and reveals the significant association between CKD progression and thyroid dysfunction and hyperleptinemia.

\section{Acknowledgment}

The authors would like to thank the Department of Biology, College of Science, Mustansiryiah University (www.uomustansiriyah.edu.iq), Baghdad, Iraq, for supporting this project.

\section{Authors' declaration:}

- Conflicts of Interest: None.

- We hereby confirm that all the Figures and Tables in the manuscript are mine ours. Besides, the Figures and images, which are not mine ours, have been given the permission for re-publication attached with the manuscript.

- The author has signed an animal welfare statement.

- Ethical Clearance: The project was approved by the local ethical committee in University of Mustansiriyah.

\section{References}

1. Mao S, Fang, L, Liu F, Jiang $\mathrm{S}, \mathrm{Wu} \mathrm{L}$, Zhang J. Leptin and chronic kidney diseases. J Recept Signal Transduct Res. 2018 Apr ; 38(2): 89-94.

2. Kannan A, Sriramakrishnan V, Kannan B, Anandan H. Thyroid Function Abnormalities in Patients with Chronic Kidney Disease - A Prospective Study. Int J Sci Stud. 2017 July; 5(4): 68-72.

3. Maia AL, Goemann IM, Meyer EL, Wajner SM. Deiodinases: the balance of thyroid hormone: type 1 iodothyronine deiodinase in human physiology and disease. J Endocrinol. 2011Jun ; 209(3): 283-297.

4. Malyszko J, Wolczynski S, Mysliwiec M. Adiponectin, leptin and thyroid hormones in patients with chronic renal failure and on renal replacement therapy: are they related?. Nephrol Dial Transplant. 2006 Jan; 21(1): 145-152.

5. Keerthana BL, Kumar TA. Study of Thyroid and Lipid Profile in Chronic Kidney Disease. Int J Med Health Res. 2016 Mar; 2(3): 6-9.

6. Montazerifar F, Mansour K, Zahra H, Mahla P. Study of serum levels of leptin, C-reactive protein and nutritional status in hemodialysis patients. Iran Red Crescent Med J. 2015 Aug; 17(8): 1-5. 
7. Shankar A, Syamala S, Xiao J, Muntner P. Relationship between plasma leptin level and chronic kidney disease. Int J Nephrol. 2012 May; 2012(6): 1-6.

8. Gunta SS, Mak RH. Ghrelin and leptin pathophysiology in chronic kidney disease. Pediatr Nephrol, 2013 Apr; 28(4): 611-616.

9. Suneja M, Murry DJ, Stokes JB, Lim VS. Hormonal regulation of energy-protein homeostasis in hemodialysis patients: an anorexigenic profile that may predispose to adverse cardiovascular outcomes. Am J Physiol Endocrinol Metab. 2011 Jan; 300 : 55-64.

10. Tsai J. The association of serum leptin levels with metabolic diseases. Tzu Chi Med J. 2017 Oct-Dec; 29 (4): 192-196.

11. Hossain MM, Shah K, Begum N, Ahmed P. Islam, A.K. and Chowdhury, N.I. Thyroid Functional Status in Chronic Kidney Disease. Bangladesh J Nucl Med (2015); 18(2):141-144

12. Briffa JF, McAinch AJ, Poronnik P, Hryciw DH. Adipokines as a link between obesity and chronic kidney disease. Am J Physiol Renal Physiol. 2013 Dec; 305(12):1629-1636.

13. Yaman H. Low triiodothyronine alters flow mediated vasodilatation in advanced nondiabetic kidney disease. Am J Nephrol. 2011; 33(1):25-32.

14. Tsimihodimos V, Mitrogianni Z, Elisaf M. Dyslipidemia Associated with chronic kidney disease. Open Cardiovasc Med J. 2011 Feb; 5(1): 41-48.

15. Rajeev G, Chickballapur RW, Vijayalakshmi R, Swathi M, Kumar S. Evaluation of thyroid hormone levels in chronic kidney disease patients. Saudi J Kidney Dis Transpl. 2015 Jan; 26(1): 90-93.

16. Singh N, Kaur S, Jain A, Thakur A. Serum C-reactive protein and leptin for assessment of nutritional status in patients on maintenance hemodialysis. Indian $\mathbf{J}$ Nephrol. 2012 Nov-Dec; 22(6): 419-423.

17. Swaminathan K, Rajesh S, Avudaiappan S. A Study of Thyroid Function Abnormalities in Patients with Chronic Kidney Disease. J Dent Med Sci. 2016 Aug; 15(8): 7-15.

18. Khatiwada S, Rajendra KC, Gautam S, Lamsal M, Baral N. Thyroid dysfunction and dyslipidemia in chronic kidney disease patients. BMC Endocr Disord. 2015 Oct; 15(1): 65.

19. Aminzadeh MA, Pahl MV, Barton CH, Nosratola NS, Vaziri D. Human uraemic plasma stimulates release of leptin and uptake of tumour necrosis factor- $\alpha$ in visceral adipocytes . Nephrol Dial Transplant. 2009 Dec ; 24(12): 3626-3631.

20. Kalantar-Zadeh K. So, Is Leptin Good or Bad in Chronic Kidney Disease? OBESITY. 2007 Jun; 15(6): 1343-1344.

21. Kuczera P, Adamczak M, Wiecek A. Endocrine abnormalities in patients with chronic kidney diseases. Sec. of Med. Sci, 2015; 36(2): 109-118.

22. Ghazizadeh SH, Lesanpezeshki M.Reproduction in Women with End-Stage Renal Disease and Effect of Kidney Transplantation. Iran J Kidney Dis. 2007 Jul; 1(1): 12-15.

23. Bates SH, Myers MG. The role of leptin receptor signaling in feeding and neuroendocrine function. Trends Endocrinol Metab. 2003 Dec; 14(10): 447-452.

24. Choobineh H, Dehghani SJ, Alizadeh S, Ghobadi DV, Saiepour N, Meshkani R. Evaluation of Leptin Levels in Major beta-Thalassemic Patients. IJHOSCR. 2009 Jan; 3(4):1-4.

25. Shahramian I, Noori N, Ramezani A, Sharafi E, Akhlaghi E. Correlation between serum leptin level and thyroid hormones in children with major betathalassemia. Iran J Ped Hematol Oncol. 2013 Oct; 3(4):149-153.

26. Hsieh CJ, Wang PW, Wang ST, Liu RT, Tung SC, Chien WY. Serum leptin concentrations of patients with sequential thyroid function changes. Clin Endocrinol (Oxf). 2002 Jul; 57(1): 29-34.

27. Corbetta S, Englaro P, Giambona S, Persani L, Blum WF, Beck-Peccoz P. Lack of effects of circulating thyroid hormone levels on serum leptin concentrations. Eur J Endocrinol. 1997 Dec ; 137(6): 695-663.

28. Ibrahim MK, Al-Samarrai AH, Khudhair KA. Association Between Leptin Hormone and Thyroid Hormone Levels in Hypothyroid, Hyprethyroid and Euthyroid Subjects. Front Biomed Sci. 2016 Oct; 1(2): 39-44. 
قصور الغدة الدرقية واللبتين لدى المرضى العراقيين المصابين بأمراض الفشل الكلوي المزمن

علي جاسم هاشم الساعدي
1

نوري محمد لعيبي
عذراء خلف فلحي 1

1ققسم علوم الحياة، كلية العلوم، الجامعة المستنصرية، بغداد، العراق.

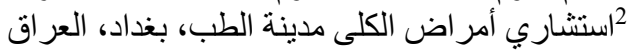

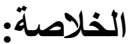

هدفت الدراسة الحالية إلى تقييم آثار مرض الفتل الكلوي المزمن على هرمونات الغدة الدرقية و هرمون اللبتين من خلال تقييم مستويات

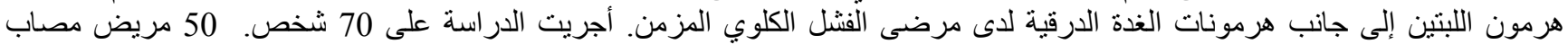

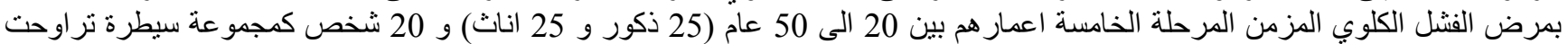

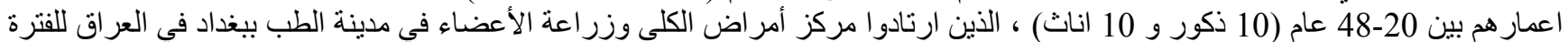

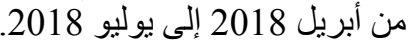

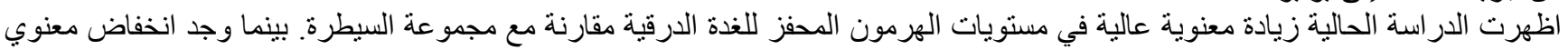

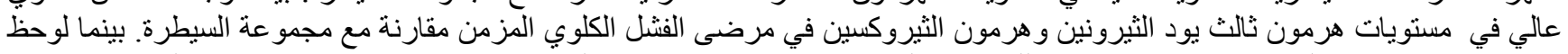

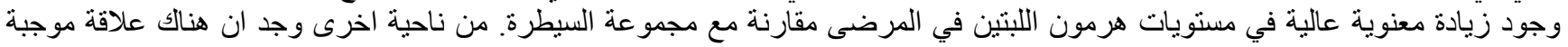

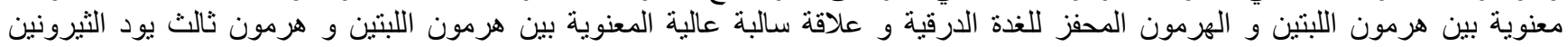
وهرمون الثيروكسين.

الكلمات المفتاحية: الفثل الكلوي المزمن، قصور الغدة الدرقية، الهرمون المحفز للغدة الدرقية، هرمون ثالث يود الثيرونين ،هرمون الثيروكسين 